\title{
Leaf Area Index, Water Index, and Red : Far Red Ratio Calculated by Spectral Reflectance and its Relation to Plant Architecture and Cut Rose Production
}

\author{
Libertad Mascarini' ${ }^{1}$, Gabriel A. Lorenzo, and Fernando Vilella \\ Department of Floriculture, Faculty of Agronomy, University of Buenos Aires, Av. San Martín 4453 \\ (1417), Ciudad de Buenos Aires, Argentina
}

\begin{abstract}
AdDitional INDEX wORDs. R:FR, blue light, remote sensors, normalized difference vegetation index, bent shoots, cut rose quality, Rosa $\times$ hybrida
\end{abstract}

\begin{abstract}
In roses (Rosa $\times$ hybrida L.), the bending of branches is a technique that modifies the canopy of the plant and could affect such parameters as the leaf area index (LAI), the quality of reflected light, and the water index (WI) of the plant. The measurement of spectral reflectance with remote sensors is a nondestructive, quick, and simple method to study these parameters. The aim of this paper is to quantify the modification of reflected radiation quality, the LAI and the water index of the plant with different canopies, and its impact on flowering and the number and quality of flowers produced. In $R$. xhybrida 'Terracotta', using the spectral crop reflectance, the red : far red ratio [red $(R)=$ $680 \mathrm{~nm}$; far red $(\mathrm{FR})=730 \mathrm{~nm}$ ], percentage of blue light of reflected radiation, and vegetation indices [normalized difference vegetation index (NDVI), simple ratio index (SRI), water index (WI)] were calculated in two architectural managements: traditional (upright hedge) and bent shoot. NDVI had a greater correlation with LAI than SRI $\left(r^{2}=\right.$ 0.98 and 0.85 , respectively), but SRI was more reliable for LAI values of 1 to 3.5 . The bent shoot system compared to the traditional one decreased the R:FR ratio of reflected radiation and increased LAI and plant water content. These changes were related to a higher commercial quality of the flowers (longer flowering shoots with a larger stem diameter and fresh weight), although there was no significant difference in the number of flowers harvested. The period that showed the largest difference in the quality of the flower using the bent shoot system had a LAI of 2.8 vs. 1.8 with traditional management and a marked reduction in the R:FR of the light reflected by bent plants. The bent shoot system advanced the peak production by 1 month at the end of winter and improved the flowers at a time when sun radiation is limiting factor for production.
\end{abstract}

The modification of the plant architecture by means of shoots bending (Ohkawa and Suematsu, 1999; Tsujita and Blom, 1996) increases light interception. In this system, more leaves are exposed to light increasing photosynthetic efficiency (Hoog et al., 2001).

Several studies have described the relation between radiation (Maas and Bakx, 1995; van Labeke et al., 2000; Zieslin and Mor, 1990), plantation density and radiation interception (Kool et al., 1997), and LAI (Warner and Erwin, 2002) on rose production. However, we found no records of the impact of absorbed and reflected light quality and quantity on rose flowering shoot quality and yield under different canopy architectures.

Several studies show that plants regulate their metabolism and development according to the quantity and quality of light they receive (Ballaré and Casal, 2000). They present mechanisms that detect the proximity of other plants and thus trigger early evasion responses to shade (Ballaré et al., 1997). The green leaves of neighboring plants transmit and reflect more in the far red than in the red wavelength resulting in a smaller red : far red (R:FR) ratio, typical of dense crops. A low R:FR ratio in these mature vegetative state plants advances flowering (Casal et al., 2003). The blue light (B), absorbed by the cryptochromes, takes part in stem extension inhibition and flower induction in some long day plants (Runkle and Heins, 2001). Growth inhibition by blue light

Received for publication 19 May 2005. Accepted for publication 11 Feb. 2006. 'To whom reprint requests should be addressed. E-mail address: lmascari@ agro. uba.ar has been documented particularly in hypocotyls and epicotyls (Casal and Smith, 1989; Laskowski and Briggs, 1989). HérautBron et al. (2001) state that Trifolium repens L. leaf elongation when exposed to FR is caused by a preferential partition of assimilated elements to the growing organs of stolon apices. The stem extension effect is mediated by changes in cell membrane permeability that is related to increased water content in the plant (Azcón-Bieto and Talón, 2000; Salisbury and Ross, 1994).

The radiation interception by the plant, fundamentally photosynthetically active radiation $(P A R)$, depends on the LAI, which changes during plant growth and development. This association is very important because it is correlated to canopy photosynthesis and the daily production of dry mass in plants that grow free of biotic or abiotic stress (Asrar et al., 1985). In 'Mercedes' roses, the bent shoot technique reduced the number of leaves by $25 \%$ but light interception was $89 \%$ greater in comparison to traditional management (Warner and Erwin, 2002).

According to Mascarini et al. (2003), studying the crop evolution under different canopy managements and its impact on flowering shoot quality and yield could be used in deciding which canopy management technique is better in a given cultivation area. Direct measurement of the leaf area is tedious and very time consuming and usually there are fewer plants at the end of the experiment than at the beginning because present techniques are either destructive or complex. This is where remote canopy sensors have an advantage because they are quick and simple to use, measurements are not destructive, and they make is possible to assess the temporal changes in growth and development of the whole plant in situ (Asrar et al., 1985; Holben et al., 1980). 
The precision of the LAI estimate using reflectance measurement depends on the contrast between the soil and the green leaves in a partially closed canopy. The largest contrast occurs in the near infrared band (700-1100 nm.) where leaf transmission and irradiance are highest. Leaves show the greatest absorbance in the visible region of the spectrum (400-700 nm.). A combination between visible and near infrared can be used to calculate the fraction of the incident radiation that is absorbed by the plant. Considering that spectral reflectance, radiation absorption and the leaf area are interrelated; the LAI could be determined as a function of this fraction (Asrar et al., 1984).

The LAI estimate using reflectance was applied successfully in various crops such as Triticum aestivum L. (Asrar et al., 1984), Glycine max (L.) Merr. (Holben et al., 1980), Zea mays L. (Gallo et al., 1985) Paspalum vaginatum Swartz, and Cynodon dactylon L. x C.transvaalensis Burtt-Davy (Trenholm et al., 1999). Sims and Gamon (2003) reported a normalized index to estimate the LAI for 23 species of bushes, trees, and grasses and defined a specific wavelength range for the highest precision. According to these authors, numerous studies have developed spectral indices that use these bands to predict plant water content (relative water content, leaf water potential, and/or water content as a percentage of dry mass). However, few studies have examined the relation between the total water content of the canopy and spectral reflectance indices. We found no references about indices based on different wavelength reflectance of vegetative tissues that correlate with water content, leaf area, etc., on rose plants.

Based on the above information, we hypothesize that: 1) bent stems systems modify light quality by reducing the R:FR ratio of the reflected radiation in a similar manner as neighboring plants do; 2) a smaller R:FR ratio promotes stem extension that remain upright, have a higher water content, and faster flower initiation; and 3) the bent shoot system has a greater LAI and radiation interception and consequently a higher photosynthesis rate that results in a better rose flowering shoot quality.

The objective of this research was to assess the changes in light quality, LAI, plant water content, and their impact on rose flowering shoot quality and yield calculated using spectral reflectance in different rose canopy managements.

\section{Materials and Methods}

The experiment was carried out at the School of Agronomy of the Univ. of Buenos Aires (lat. $34^{\circ} 55^{\prime} \mathrm{S}$, long. $58^{\circ} 29^{\prime} \mathrm{W}, 25$ $\mathrm{m}$ above sea level). The mean temperature of the coldest month is $10.3{ }^{\circ} \mathrm{C}$ (July) and the warmest is $23.4{ }^{\circ} \mathrm{C}$ (January). Monthly values of global radiation are $7.03 \mathrm{MJ} \cdot \mathrm{m}^{-2}$ (July) and 22.98 $\mathrm{MJ} \cdot \mathrm{m}^{-2}$ (January). The mean potential evapotranspiration inside the greenhouse, calculated using the Penman-Monteith method, was $2.95 \mathrm{~mm} \cdot \mathrm{d}^{-1}$ (July) and $6 \mathrm{~mm} \cdot \mathrm{d}^{-1}$ (January) (Mascarini et al., 2001).

In Dec. 2000, 3-year-old Rosa xhybrida 'Terracota' plants grafted on R. manetti L. in June 1998, were planted in 20-m-long, 0.40 -m-wide, and 0.25 -m-deep containers, full of perlite, at a plant density of 8.3 plants $/ \mathrm{m}^{2}$. Measurements started at the second year of growth. Two canopy architecture management systems were used: 1) traditional, in which the branches are left to grow (Fainstein, 1997; Ferrer Martí and Palomo, 1986), and 2) shoot bending, in which the lateral branches of the first order and later all of the stems without flowers or with flowering shoots of no commercial value are bent to a lower than horizontal position in order to expose more leaves to the light (Fainstein, 1997; Ohkawa and Suematsu, 1999; Tsujita and Blom, 1996). Flowering shoots were harvested by cutting stems above the second five-leaflet leaf in both management systems. Plants were placed in a $0.15-\mathrm{mm}$ thick polyethylene-covered steel greenhouse, orientated in northsouth direction, which reduces the incident radiation by $20 \%$, with automatic ventilation, heating and drip fertigation systems. The nutrient solution contained (in $\mathrm{mM}$ ): $1.5 \mathrm{NO}_{3}^{-}, 0.25 \mathrm{H}_{2} \mathrm{PO}_{4}^{-}, 1.5$ $\mathrm{K}^{+}, 1.0 \mathrm{Ca}^{2+}, 0.5 \mathrm{Mg}^{2+}, 1.4 \mathrm{SO}_{4}^{2-;}$, half-strength Hoagland's micronutrient concentration and $1 \mathrm{mg} \cdot \mathrm{L}^{-1} \mathrm{Fe}$ as Fe-EDDHA(Cabrera et al., 1996). Minimal and maximal inside greenhouse temperature were 16 and $28^{\circ} \mathrm{C}$, respectively. Minimal and maximal average global radiation inside greenhouse were 5.16 and $12.88 \mathrm{MJ} \cdot \mathrm{m}^{-2}$ in July 2002 and Dec. 2002, respectively. Crop reflectance was measured with a handheld multispectral radiometer (MRS16C 9; Cropscan, Rochester, Minn.) at 450, 500, 550, 610, 660, 680, $710,730,760,780,810,870,950,1080,1220$ and $1600 \mathrm{~nm}$. Each band had a half peak band width of between 5 and $15 \mathrm{~nm}$. The sensor head was mounted on an adjustable pole that was parallel to the ground surface with a field of view of between 0.8 to $1.0 \mathrm{~m}$ diameter. The measurements were taken approximately every 15 d during 5 months, in full-sun days, between 1100 and $1300 \mathrm{HR}$. The substrate was covered with a black cloth to prevent undesirable reflection from the perlite. Seven measurements were taken per block, six of them by placing the spectroradiometer $0.75 \mathrm{~m}$ above the plant canopy, perpendicular to the soil, and another on a leveled white reference panel (100\% reflectance). With these data we calculated several plant indices and assessed the quality of the radiation reflected as described below.

1) SRI (Birth and McVey, 1968). This is the ratio between reflectance percent in the infrared region $(800-1100 \mathrm{~nm})$ and reflectance percent in the red region (600-700 $\mathrm{nm}$ ). The wavelengths used in this paper were $680 \mathrm{~nm}$ (reflection in $\mathrm{R}_{680}$ ) and $810 \mathrm{~nm}$ (reflection in near infrared, $\mathrm{R}_{810}$ ).

$$
\mathrm{SRI}=\mathrm{R}_{810} / \mathrm{R}_{680}
$$

2) NDVI (Sims and Gamon, 2003). The wavelengths here are the same as those used in the SRI.

$$
\mathrm{NDVI}_{680}=\left(\mathrm{R}_{810}-\mathrm{R}_{680}\right) /\left(\mathrm{R}_{810}+\mathrm{R}_{680}\right)
$$

$3)$ The two indices described above are based on the strongest chlorophyll absorption band. Reflectance in the near infrared characterizes the cellular structure of the leaf and it is high if plants does not present stress conditions. Starting from $1400 \mathrm{~nm}$ the radiation absorption increases due to the water contained in the leaf, and crop reflectance is increased under water stress conditions (Joel et al., 1997; Wiegand and Richarson, 1990).

Because water has several absorption maxima throughout the infrared region of the spectrum quite a number of different indices and techniques have been developed for estimation of water. The simplest WI is a ratio between reflectance at a reference wavelength where water does not absorb and a wavelength where water does absorb (Sims and Gamon, 2003). They used the following general equation to test the effect of variation in the strength of light absorption by water across the spectrum:

$$
\mathrm{WI}_{\mathrm{xxx}}=\mathrm{R}_{900} / \mathrm{R}_{\mathrm{xxx}}
$$

where the reference wavelength is held constant at $900 \mathrm{~nm}$ but the index wavelength (xxx) is varied. They found the good correlation between WI and water content in the 1520-1540-nm region. In our case we used the following equation with $1600 \mathrm{~nm}$ as index wavelength where the absorption was strongest:

$$
\mathrm{WI}_{1600}=\mathrm{R}_{900} / \mathrm{R}_{1600}
$$

4) The R:FR ratio was calculated as the quotient between radiation reflected in the length of the $R$ wavelength $(680 \mathrm{~nm})$ and the percentage of the radiation reflected in the FR band $(730 \mathrm{~nm})$. 
5) Reflected blue light was calculated for each canopy management using the reflectance percentage of each plant in the 450-nm wavelength.

6) In a plot of known area one plant was isolated by means of a black cloth, and reflected radiation was measured. Six plants were added to the plot (one at a time) and the reflected radiation was measured. We calculated reflectance index (SRI and NDVI) in each case. Thus we obtained six levels of LAI and their corresponding reflectance index. The procedure was repeated in five randomly chosen places. The LAI values were measured destructively with an area meter (LI-3100; LI-COR, Lincoln, Nebr.) These values and SRI and NDVI were used to calculate a simple regression curve that was used for the determination of the LAI values from spectral reflectance index.

Flowering shoots were cut daily and stem length, stem diameter, bud length, fresh weight and the total number were recorded.

Three replications were made in complete randomly chosen blocks, with 20 plants per block and three blocks per treatment. Blocks were chosen considering a radiation gradient, related to greenhouse north-south orientation. The data were analyzed using analysis of variance and simple regression [InfoStat/Profesional, version 1.1 (Universidad Nacional de Córdoba, 2002)].

\section{Results}

Plant reflectance measurement and LaI calculation. Significant differences in reflected radiation percentage at wavelengths higher than $730 \mathrm{~nm}$ were found between the two canopy management systems (Fig. 1, values recorded on 26 Sept. 2002).

The best fit between SRI and LAI was linear and the regression coefficient was $R^{2}=0.85$ (Fig. 2). The best fit between NDVI and LAI was exponential and the regression coefficient was $R^{2}$ $=0.98$ (Fig. 3).

LAI between 1 and 3.5 is recommended for optimizing the photosynthetic area in the bent shoot system (Pien et al., 2001). We validated the models with our measured data, and verified the lack of fit between NDVI and LAI in the higher values; therefore we assumed that SRI was more reliable in our experiment.

The LAI was calculated between August and December using the reflectance data with the regression equation $\mathrm{LAI}=(0.2423$ SRI) -0.6704 (Fig. 4). Bent shoots management resulted in a

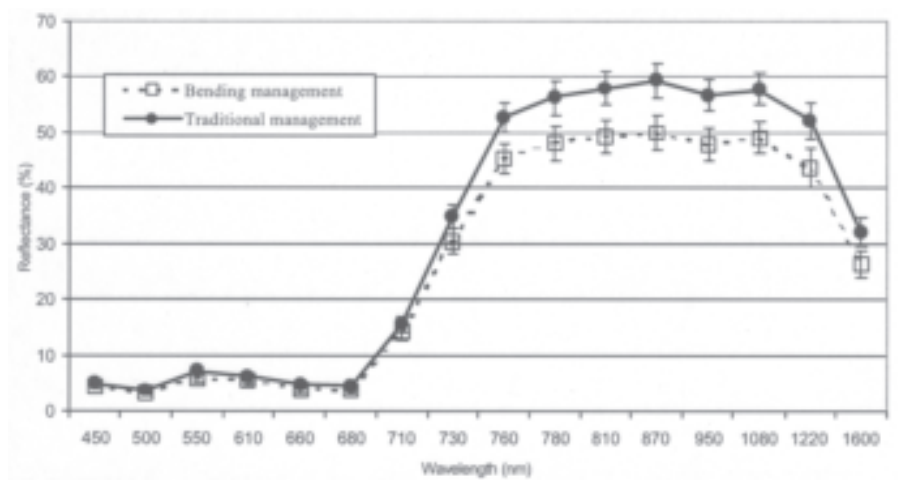

Fig. 1. Spectral reflectance as a percent of maximum (white reference panel) of rose crops under two management systems at wavelengths from 450 to 1600 $\mathrm{nm}$, measured during a sunny day between 1100 and 1300 HR. Traditional management $=$ leaving all of the branches upright (continuous line); bending management $=$ lateral branches of the first order and later all of the stems without flowers or with commercially unviable flowers are bent to a horizontal position at an angle $\geq 90^{\circ}$ (dashed line). Vertical bars are $2 \times \operatorname{SE}(\mathrm{n}=9)$.

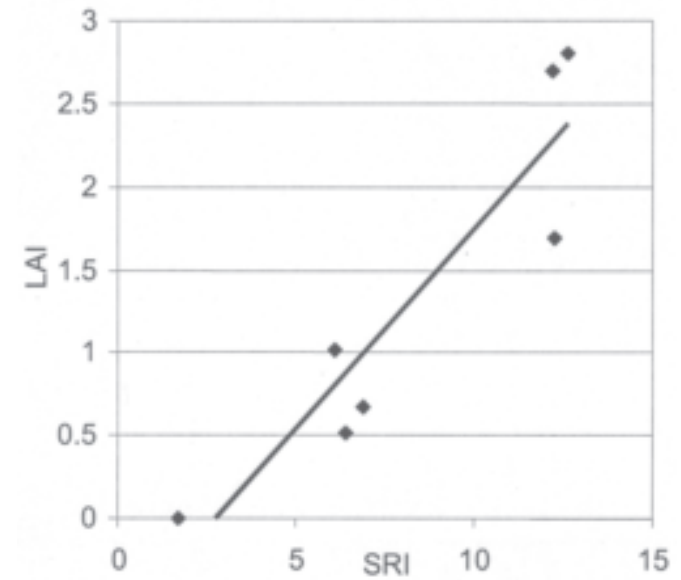

Fig. 2. Relationship between measured leaf area index (LAI) and simple reflectance index (SRI) calculated by spectral reflectance in 680 - and 810 -nm wavelengths for a cut rose crop. Symbols represent measured data; the line represents the best fit $\left[\mathrm{LAI}=(0.2423 \mathrm{SRI})-0.6704, R^{2}=0.8517\right]$.

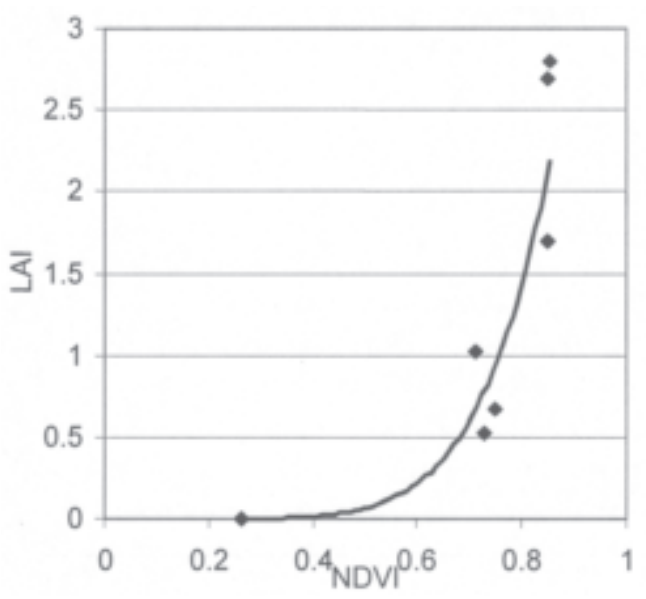

Fig. 3. Relationship between measured leaf area index (LAI) and normalized difference vegetation index (NDVI) calculated by spectral reflectance in 680and 810-nm wavelengths for a cut rose crop. Symbols represent measured data; the line represents the best fit (LAI $=6.1953$ NDVI $\left.{ }^{6.5401}, R^{2}=0.9866\right)$.

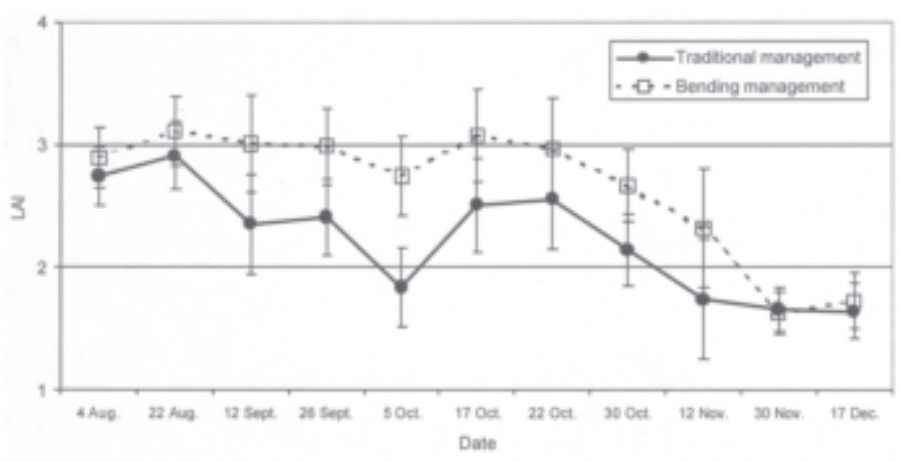

Fig. 4. Leaf area index (LAI) estimation from simple reflectance index (SRI) in a cut rose crop under two management systems. Traditional management = leaving all branches upright (continuous line); bending management = lateral branches of the first order and later all of the stems without flowers or with commercially unviable flowers are bent to a horizontal position at an angle equal to or $>90^{\circ}$ (dashed line). Dates are the days when measurements were taken. Vertical bars are $2 \times \operatorname{SE}(n=9)$. 
higher LAI between August-November, and became similar in both management systems in Dec. 2002, with large differences at the end of winter and beginning of spring (Sept.-Oct. 2002).

LIGHT QUALITY AND WATER INDEX. The calculated R:FR ratio for the bent shoot system was significantly smaller than the one for the traditional management system at the end of winter and spring (September-November) (Fig. 5). The blue light reflected by plants of the bent shoot system during most of the period analyzed is significantly smaller than the one for the traditional system (Fig. 6).

During the spring period, most WI values for the bent shoot management system were higher than those for the traditional management (Fig. 7).

FLOWER PRODUCTION AND QUALITY. The number of flowers per square meter harvested from Apr. to Dec. 2002 was similar in both the traditional and the bent shoot systems (18.7 and 17.3, respectively) but the number of long flowering shoots (more than $50 \mathrm{~cm}$ ) was significantly higher with the bent shoot system than with the traditional one: 10.6 vs. 7.5 , respectively (Table 1 ).

We observed three peaks of production in both management systems during April-December (Fig. 8). The first peak occurs in the second half of May in both treatments, and the number of flowering shoots produced at that time was similar. After the winter decline, the second peak of rose production with the bent shoot management system occurs more than a month earlier than the one for the traditional management system with significant differences in the number of long stems (Fig. 9, Table 1). There were no significant differences in the production of flowering shoots shorter than $50 \mathrm{~cm}$ in the whole period. (Fig. 10)

Considering a 60-d production flush (second half of July to the first half of September), the cumulative production was 4.5 and 3.8 flowering shoots $/ \mathrm{m}^{2}$ in the bent shoot and traditional systems, respectively, but there were no differences in the number of long stems: 2.7 vs. 2.3 flowers $/ \mathrm{m}^{2}$, respectively (Table 1 ). Stem diameter and fresh weight were greater in the bent shoot system (Figs. 11 and 12).

During the third production flush (October-November) there were no significant differences in the cumulative number of flowering shoots ( 7 flowers $/ \mathrm{m}^{2}$ ) but plants in the bent shoot system had a larger number of long stems harvested (4.3 vs. 2.5 flowers $/ \mathrm{m}^{2}$ ) (Table 1) with larger stem diameters and fresh weights (Figs. 11 and 12).

\section{Discussion}

Light QUALITY, LAI, AND FLOWER PRODUCTION. The results obtained in this research suggest that the bent stems form a "floor" of green matter that induces a response similar to that of neighboring plants. Green leaves of neighboring plants transmit and reflect more strongly on the FR than on the R wave band resulting in a smaller R:FR ratio, typical of dense crops. In a mature plant, a low R:FR ratio advances flowering (Casal et al., 2003). This could explain the early production peak at August in the bent shoot management system. A smaller R:FR ratio and less blue light in the radiation reflected by the bent shoot system could explain the extension of the stems compared to the traditional one (Ballaré et al., 1997; Casal and Smith, 1989; Runkle and Heins, 2001).

The earlier flowering initiation occurred at the end of winter (August) in the bent shoot system when the radiation was a limiting factor under our experimental crop conditions. At this moment, the number of flowering shoots was higher than in the

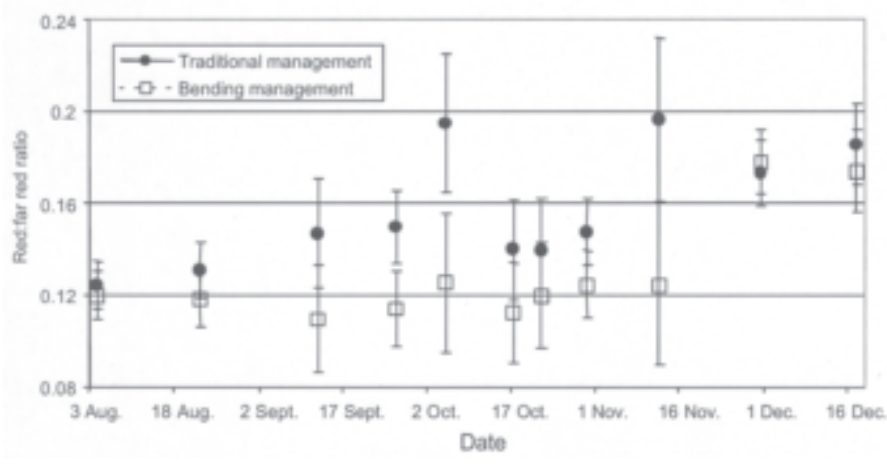

Fig. 5. Red : far red ratio (R:FR) measured by spectral reflectance in a cut rose crop under two management systems. Traditional management = leaving all branches upright (continuous line); bending management $=$ lateral branches of the first order and later all of the stems without flowers or with commercially unviable flowers are bent to a horizontal position at an angle $\geq 90^{\circ}$ (dashed line). Vertical bars are $2 \times \operatorname{SE}(n=9)$.

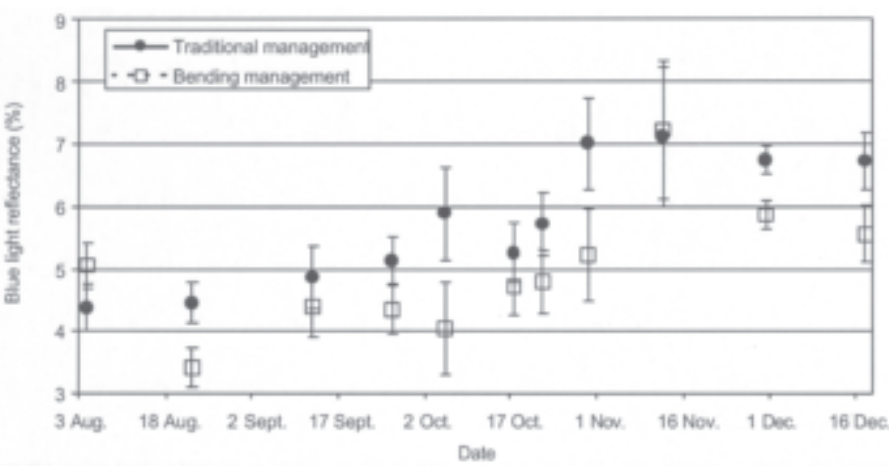

Fig. 6. Evolution of reflected radiation - incident radiation ratio at the wavelength of $450 \mathrm{~nm}$ (blue light) in a cut rose crop under two management systems. Traditional management = leaving all of the branches upright (continuous line); bending management $=$ lateral branches of the first order and later all of the stems without flowers or with commercially unviable flowers are bent to a horizontal position at an angle $\geq 90^{\circ}$ (dashed line). Vertical bars are $2 \times \operatorname{SE}(n=9)$.

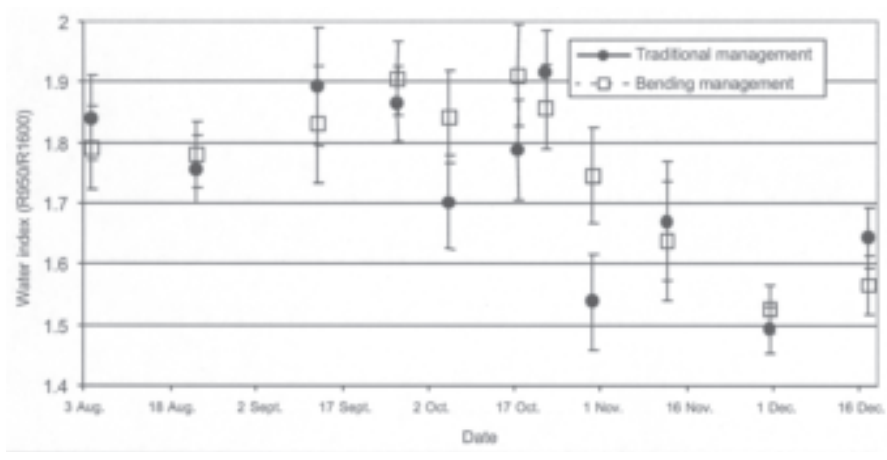

Fig. 7. Evolution of water index (WI) calculated with the reflectance at wavelength of 950 and $1600 \mathrm{~nm}$, in a cut rose crop under two management systems. Traditional management = leaving all branches upright (continuous line); bending management $=$ lateral branches of the first order and later all of the stems without flowers or with commercially unviable flowers are bent to a horizontal position at an angle $\geq 90^{\circ}$ (dashed line). Vertical bars are $2 \times \mathrm{SE}(\mathrm{n}=9)$. 
Table 1. Number and quality of flowering shoots harvested in a cut rose crop under two management systems. Data are average of three replications.

\begin{tabular}{|c|c|c|c|c|c|c|c|}
\hline Period & Management $^{\mathrm{z}}$ & $\begin{array}{c}\text { Flowering } \\
\text { shoots } \\
\left(\text { no. } / \mathrm{m}^{2}\right) \\
\end{array}$ & $\begin{array}{l}\text { Signi- } \\
\text { ficance }\end{array}$ & $\begin{array}{c}\text { Flowering } \\
\text { shoots longer } \\
\text { than } 50 \mathrm{~cm} \\
\left(\text { no. } / \mathrm{m}^{2}\right) \\
\end{array}$ & $\begin{array}{l}\text { Signi- } \\
\text { ficance }\end{array}$ & $\begin{array}{c}\text { Flowering } \\
\text { shoots longer } \\
\text { than } 50 \mathrm{~cm} \\
(\%) \\
\end{array}$ & $\begin{array}{c}\text { Flowering } \\
\text { shoots shorter } \\
\text { than } 50 \mathrm{~cm} \\
(\%)\end{array}$ \\
\hline \multirow{2}{*}{ April-December } & Traditional & 17.3 & \multirow{2}{*}{ NS } & 7.5 & \multirow{2}{*}{$*$} & 43.4 & 56.6 \\
\hline & Bending & 18.7 & & 10.6 & & 56.4 & 43.6 \\
\hline \multirow{2}{*}{$\begin{array}{l}\text { 2nd flush ( } 2 \text { nd half } \\
\text { July-1st half } \\
\text { September) }\end{array}$} & Traditional & 3.8 & \multirow{2}{*}{${ }^{*}$} & 2.3 & \multirow{2}{*}{ NS } & 59.4 & 40.6 \\
\hline & Bending & 4.5 & & 2.7 & & 59.8 & 40.2 \\
\hline \multirow{2}{*}{$\begin{array}{l}\text { 3rd flush (October- } \\
\text { November) }\end{array}$} & Traditional & 7.0 & \multirow{2}{*}{ NS } & 2.5 & & 36.0 & 64.0 \\
\hline & Bending & 7.1 & & 4.3 & & 60.5 & 39.5 \\
\hline
\end{tabular}

${ }^{z}$ Traditional management $=$ leaving all of the branches upright; bending management: lateral branches of the first order and later all of the stems without flowers or with commercially unviable flowers are bent to a horizontal position at an angle $\geq 90^{\circ}$.

NS, *,*****Nonsignificant or significant at $P<0.05,0.01$, or 0.001 , respectively.

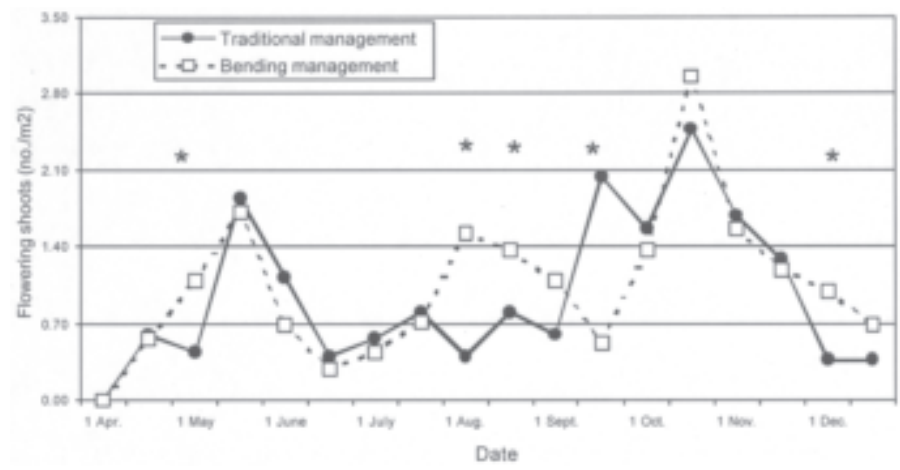

Fig. 8. Bi-weekly production of flowering shoots in a cut rose crop under two management systems. Traditional management = leaving all branches upright (continuous line); bending management $=$ lateral branches of the first order and later all of the stems without flowers or with commercially unviable flowers are bent to a horizontal position at an angle $\geq 90^{\circ}$ (dashed line); * significant at $P<0.05(\mathrm{n}=3)$.

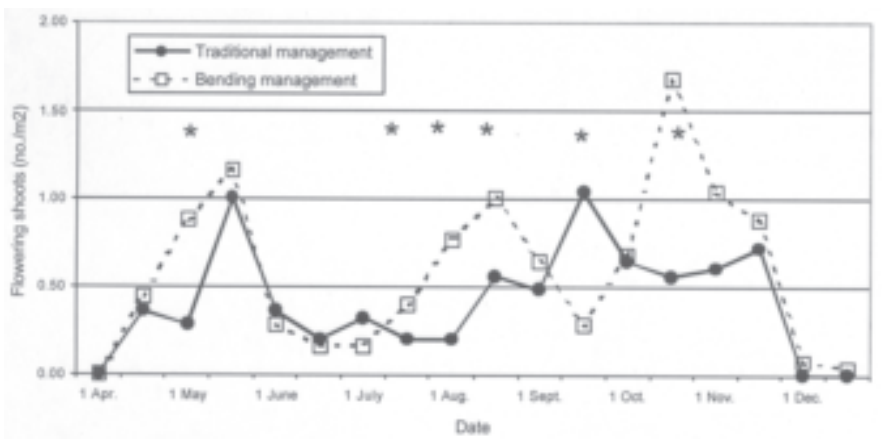

Fig. 9. Bi-weekly production of flowering shoots longer than $50 \mathrm{~cm}$ in a cut rose crop under two management systems. Traditional management $=$ leaving all branches upright (continuous line); bending management $=$ lateral branches of the first order and later all of the stems without flowers or with commercially unviable flowers are bent to a horizontal position at an angle $\geq 90^{\circ}$ (dashed line); * significant at $P<0.05(\mathrm{n}=3)$.

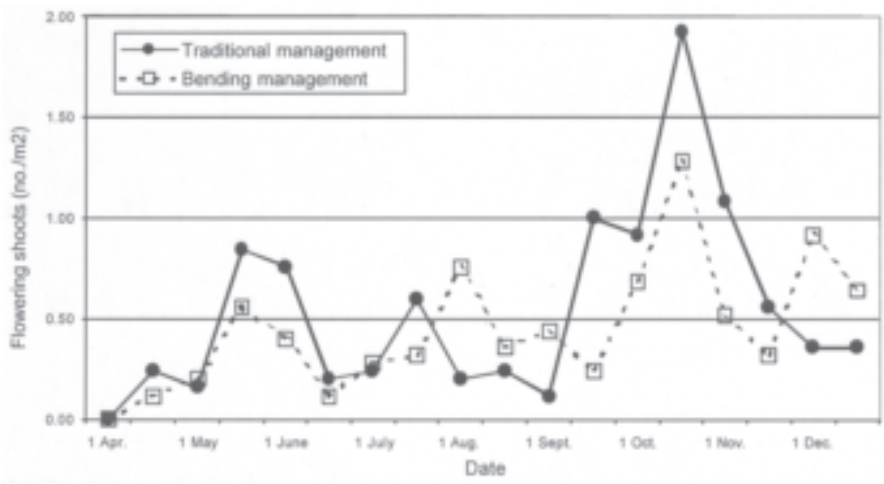

Fig. 10. Bi-weekly production of flower shoots shorter than $50 \mathrm{~cm}$ in a rose crop under two management systems. Traditional management = leaving all branches upright (continuous line); bending management $=$ lateral branches of the first order and later all of the stems without flowers or with commercially unviable flowers are bent to a horizontal position at an angle $\geq 90^{\circ}$ (dashed line). There were no significant differences at $P=0.05(\mathrm{n}=3)$.

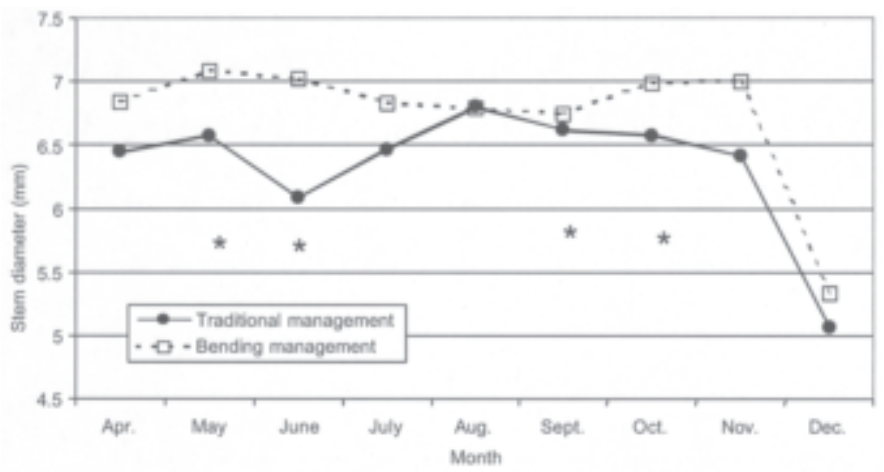

Fig. 11. Monthly average flowering shoot diameter in a rose crop under two management systems. Traditional management = leaving all branches upright (continuous line); bending management = lateral branches of the first order and later all of the stems without flowers or with commercially unviable flowers are bent to a horizontal position at an angle $\geq 90^{\circ}$ (dashed line); * significant at $P<0.05(\mathrm{n}=3)$. 


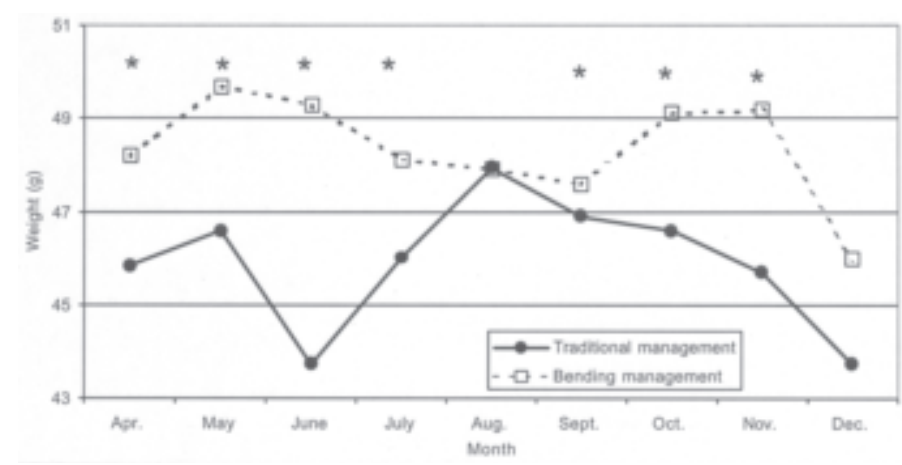

Fig. 12. Monthly average flowering shoot fresh weight in a rose crop under two management systems. Traditional management $=$ leaving all branches upright (continuous line); bending management = lateral branches of the first order and later all of the stems without flowers or with commercially unviable flowers are bent to a horizontal position at an angle $\geq 90^{\circ}$ (dashed line); * significant at $P<0.05(\mathrm{n}=3)$.

traditional system, and this is important because roses reach the highest price in the market. In the third production peak during October-November, when radiation was sufficient, the smaller $\mathrm{R}: F R$ ratio and the reduced blue light in the bent shoot system produced longer stems. Mother's Day is in the middle of this period (third week of October), with high demand and therefore better prices, especially for high quality flowers.

The period with the highest difference in flower quality in the bent shoot system coincided with a LAI $=2.8$ vs. 1.8 for the traditional management.

With a higher LAI, the efficiency of light interception is increased (Kool and Lenssen, 1997; Sivakumar and Virmani, 1984). Higher light interception increases the crop photosynthesis rate, enhancing dry mass gain (Wilson, 1981). The functional relationship between LAI and high flowering shoot quality may lead to a higher photosynthesis rate resulting in more photo-assimilates being available for growth. A smaller R:FR ratio however would cause a preferential partition of assimilates towards the growing organs (Héraut-Bron et al., 2001). All of the above could explain the improvement in flowering shoots quality: larger stem and bud diameters and larger fresh weight.

In the bent shoot system LAI is composed of bent shoots and upright developing flowering shoots, while in the traditional system all shoots appeared upright. By October the LAI was 3.07 vs. 2.51 in bent shoot and traditional management systems, respectively, but by December it became similar in both treatments (1.73 vs. 1.64, respectively). The strong decrease of LAI in the bent shoot system since October could be explained by two facts. Firstly, this moment coincided with the highest peak of harvest of flowering shoots, and as this was longer in the bent shoot system than in the traditional management, more leaves were removed. Secondly, few shoots were bent as there were few low quality flowering shoots, so this contributed to a strong decrease of the LAI since October-December. LAI may vary in each plant and in each season, and not always is influenced by bending (Hoog et al., 2001).

WI, R:FR, AND STEM ELONGATION. The bent shoot system showed significant differences in WI coincident with significant differences in LAI, R:FR and production of longer flowering shoots in October-November, as compared with traditional management system. WI is related to the water content of the tissues (leaves, thin stems, and green fruit that are the most photosynthetic), and it may also be possible to measure the quantity of photosynthetically active tissue (Sims and Gamon, 2003).
A lower R:FR ratio promotes changes in cell membrane permeability and the tissue water content increases (AzcónBieto and Talón, 2000; Salisbury and Ross, 1994). This would explain the higher stem elongation in the bent shoot system in October-December.

ROSE PLANT ARCHITECTURE MANAGEMENT SYSTEM. The quality of the $R$. $\times$ hybrida 'Terracota' flowering shoots improved with the bent shoot technique while the productivity remained the same when compared to the one from the upright management system. This is important because there is evidence that the bent shoot technique improves quality while reducing productivity in other varieties (Hoog et al., 2001).

The bent shoot technique can be recommended at times when radiation limits rose production, as it occurs in high latitudes. In midsummer, when radiation is abundant and demand and prices drop, it is advisable to bend the largest number of shoots possible, even commercially viable stems, in order to prepare a "floor" of green leaves for the autumn which will increase radiation interception and photosynthesis at a time when solar radiation decreases and becomes a limiting factor. This would make it possible to improve the quality and number of the flowering shoots at a time when demand and prices are high. In order to obtain peak production in these dates, it is necessary to consider that bent shoot system would produce earlier flower initiation.

SPECTRAl REFleCtanCE MEASUREMENTS. Changes in spectroradiometric signals of a crop may be indicators of the physiological status of the plants (Savé et al., 1995). This work contributes to a better understanding of the relationships between cut rose crop productivity and reflectance, and could be used in future research work in order to evaluate in situ the impact of different management techniques.

The measurement of the radiation reflected by rose plants offers a nondestructive and simple method to simultaneously assess various parameters, to allow the investigation of the ecophysiological causes of changes in flower production.

\section{Literature Cited}

Asrar G., E.T. Kanemasu, and M. Yoshida. 1985. Estimates of leaf area index from spectral reflectance of wheat under different cultural practices and solar angle. Remote Sensing Environ. 17:1-11.

Asrar, G., M. Fuchs, E.T. Kanemasu, and J.L. Hatfield. 1984. Estimating absorbed photosynthetic radiation and leaf area index from spectral reflectance in wheat. Agron. J. 76:300-306.

Azcón-Bieto, J. and M. Talón. 2000. Fotomorfogénesis: La luz como factor regulador del crecimiento, p. 377-388. In: J. Azcón-Bieto and M. Talón (eds.). Fundamentos de Fisiología Vegetal. Universitat de Barcelona, Spain.

Ballaré, C.L. and J.J. Casal. 2000. Light signals perceived by crop and weed plants. Field Crops Res. 67: 149-160.

Ballaré, C.L., A.L. Scopel, and R.A. Sanchez. 1997. Foraging for light photosensory ecology and agricultural implications. Plant Cell Environ. 20:820-825.

Birth, G.S. and G. McVey. 1968. Measuring the color of growing turf with a reflectance spectrophotometer. Agron. J. 60:640-643.

Cabrera, R.I., R.Y. Evans, and J.L. Paul. 1996. Enhancement of short term nitrogen uptake by a greenhouse roses under intermitent $\mathrm{N}$ deprivation. Plant and Soil 179:73-79

Casal, J.J. and H. Smith. 1989. Effects of blue light pretreatments on internode extension grows in mustard seedlings after the transition to darkness: Analysis of the interaction with phytochrome. J. Expt. Bot. 40:893-899.

Casal, J.J., L.G. Luccioni, K.A. Oliverio, and H.E. Boccalandro. 2003. Light, phytochrome signalling and photomorphogenesis in arabidopsis. Photochem. Photobiol. Sci. 2:625-636. 
Fainstein, R. 1997. Manual para el cultivo de rosas en Latinoamérica. 1 st ed. Editorial Ecuaoffset, Quito, Ecuador.

Ferrer Martí, F. and P.J. Palomo. 1986. La producción de rosas en cultivo protegido. 1st ed. Universal Plantas, Sevilla, Spain.

Gallo, K.P., C.S.T. Daughtry, and M.E. Bauer. 1985. Spectral estimation of absorbed photosynthetically active radiation in corn canopies. Remote Sensing Environ. 17:221-232.

Héraut-Bron, V., C. Robin, C. Varlet-Grancher, and A. Guckert. 2001. Phytochrome mediated effects on leaves of white clover: Consequences for light interception by the plant under competition for light. Ann. Bot. 88:737-743.

Holben, B.N., C.J. Tucker, and C.J. Fan. 1980. Spectral assessment of soybean leaf area and leaf biomass. Photogrammetric Eng. Remote Sensing 46:651-656.

Hoog, J., M. Warmenhoven, B. Eveleens-Clark, and N. Marissen. 2001. Effects of plant density, harvest methods and bending of branches on the production and quality roses. Acta Hort. 547:311-317.

Joel, G., J.A. Gamon, and C. Field. 1997. Production efficiency in sunflower: the role of water and nitrogen stress. Remote Sensing Environ. 62:176-188.

Kool, M.T.N. and E.F.ALenssen. 1997. Basal-shoot formation in young rose plants: Effects of bending practices and plant density. J. Hort. Sci. 72:635-644.

Kool, M.T.N., R. De Graaf, and C.H.M. Rou-Haest. 1997. Rose flower production as related to plant architecture and carbohydrate content: Effect of harvesting method and plant type. J. Hort. Sci. 72:623-633.

Laskowski, M.J. and W.R. Briggs. 1989. Regulations of pea epicotyl by blue light. Plant Physiol. 89:293-298.

Maas, F.M. and E.J. Bakx. 1995. Effects of light on growth and flowering of Rosa hybrids 'Mercedes'. J. Amer. Soc. Hort Sci 120:571-576.

Mascarini, L., G. Lorenzo, and F. Vilella. 2003. Producción y calidad de rosas para corte con y sin agobio de ramas y su relación con la respuesta al stress ambiental por fitomonitoreo, p. 241-251. In: L. Mascarini, F. Vilella, and C. Wright (eds.). Floricultura en la Argentina. Investigación y Tecnología de Producción. Editorial Facultad de Agronomía, Universidad de Buenos Aires, Buenos Aires, Argentina.

Mascarini, L., O.S. Delfino, and F. Vilella. 2001. Evapotranspiration of two Gerbera jamesonii cultivars in hydroponics: Adjustment of models for greenhouses. Acta Hort. 554:261-269.

Ohkawa, K. and M. Suematsu. 1999. Arching cultivation techniques for growing cut roses. Acta Hort. 482:47-51.
Pien, H., E. Bobelyn, R. Lemeur, and M.C. van Labeke. 2001. Optimising LAI in bent rose shoots. Acta Hort. 547:319-327.

Runkle, E.S. and R.D. Heins. 2001. Specific functions of red, far red, and blue light in flowering and stem extension of long-day plants. J. Amer. Soc. Hort. Sci. 126:275-282.

Salisbury, F.B. and C.W. Ross. 1994. Fotomorfogénesis, p. 487-514. In: F.B. Salisbury and C.W. Ross (eds.). Fisiología vegetal. Editorial Iberoamericana, México DF, México.

Savé, R., J. Peñuelas, I. Fillela, and C. Olivella. 1995. Water relations, hormonal levels, and spectral reflectance of Gerbera jamesonii Bolus subjected to chilling stress. J. Amer. Soc. Hort. Sci. 120:515-519.

Sims, D.A. and J.A. Gamon. 2003. Estimation of vegetation water content and photosynthetic tissue area from spectral reflectance: A comparison of indices based on liquid water and chlorophyll absorption features. Remote Sensing Environ. 84:526-537.

Sivakumar, M.V.K. and S.M. Virmani. 1984. Crop productivity in relation to interception photosynthetically active radiation. Agr. For. Meteorol. 31:131-141.

Trenholm, L.E., R.N. Carrow, and R.R. Duncan. 1999. Relationship of multispectral radiometry data to qualitative data in turfgrass research. Crop Sci. 39:763-769.

Tsujita, J. and T. Blom. 1996. Arching method of rose production. Rose Inc. Bul. April:33-37.

Universidad Nacional de Córdoba. 2002. InfoStat/Profesional. Versión 1.1. Universidad Nacional de Córdoba, Estadística y Biometría, Facultad de Ciencias Agrarias, Córdoba, Argentina. 15 Aug. 2002. <http://www. infostat.com.ar>.

van Labeke, M.C., P. Dambre, and M. Bodson. 2000. Effects of supplementary lighting and bending technique on growth, flowering and carbohydrate status of Rosa hybrida 'Frisco'. Acta Hort. 515:245-256.

Warner, R.M. and J.E. Erwin. 2002. Estimation of total canopy photosynthetic capacity of roses grown under two canopy management systems. Acta Hort. 580:89-93.

Wiegand, C.L. and A.J. Richardson. 1990. Use of spectral vegetation indices to infer leaf area, evapotranspiration and yield: II. Results. Agron. J. 82:630-636.

Wilson, J.W. 1981. Analysis of light interception by single plants. Ann. Bot. 48:501-505.

Zieslin, N. and Y. Mor. 1990. Light on rose. A review. Scientia Hort. 43:1-14. 